\title{
Structure and Replication of the Trachoma Agent in Cell Cultures, as shown by Electron Microscopy
}

\author{
By J. A. ARMSTRONG, R. C. VALENTINE AND CELIA FILDES \\ National Institute for Medical Research, London, N.W. 7
}

(Received 25 April 1962)

\begin{abstract}
SUMMARY
Propagation of the trachoma agent in human cell cultures has made possible the observation by electron microscopy of sequential stages in the replication of the micro-organism. Scattered reticular foci with incomplete limiting membranes were present in the cytoplasm of $\mathrm{HeLa}$ cells $12 \mathrm{hr}$. after exposure to the infectious agent in high multiplicity. After $24 \mathrm{hr}$. the foci had coalesced to give a single reticular mass. Within it there appeared large and discrete developmental forms from which, by progressive subdivision and diminution in size, typical elementary bodies were formed. The elementary bodies had a prominent limiting membrane, and a dense core within which a fibrillar nucleoid could be recognized. The controversial taxonomic status of the trachoma agent is considered briefly in the light of ultrastructural evidence.
\end{abstract}

\section{INTRODUCTION}

Members of the psittacosis group, with the related causal agents of trachoma and inclusion blennorrhoea, present an interesting and controversial problem in taxonomy (Andrewes, 1952; Bedson, 1959). Although acknowledged as obligate intracellular parasites and virus-like in size, the micro-organisms have properties that prompt misgivings about their viral nature, for they appear to have much in common with the bacteria and rickettsias. There is increasing support for the view expressed by Weiss (1955) that they are, in fact, typical of neither rickettsias nor viruses but lie somewhere between the two. The features usually cited as incompatible with a viral classification are: (i) microscopical studies have consistently upheld the view that multiplication is by binary fission of intact particles; (ii) chemical analyses indicate that the infective particles have a chemical complexity akin to that of bacteria; (iii) the occurrence of an eclipse phase is unproven; (iv) the organisms are susceptible to a variety of antibiotics and other compounds. The issue is by no means settled, however, and some recent investigations draw attention to the viruslike aspects of the psittacosis group. McCloskey \& Morgan (1961) observed that the latent phase following inoculation of $L$ cell cultures with psittacosis virus could be prolonged for $24 \mathrm{hr}$. by withholding certain vitamins and amino acids: during this period infectivity was lost, and no viral structures or inclusion bodies were detected by light or electron microscopy. Infectious virus reappeared in the system within $24 \mathrm{hr}$. of rectifying the nutritional deficiency. Tanami, Pollard \& Starr (1961) studied the effects of pyrimidine analogues and $p$-fluorophenylalanine on the growth curve of psittacosis virus, also in tissue cultures. It was inferred that a lag of $10 \mathrm{hr}$. 
occurred between viral DNA synthesis and its incorporation into infectious particles, and it was suggested that replication of 'naked' DNA indicates an essentially viral mode of multiplication. In similar vein Becker, Mashiah \& Bernkopf (1962), describing a growth cycle of some $\mathbf{7 2} \mathrm{hr}$. for the trachoma agent in vitro, reported that it passed initially through a non-infectious phase lasting $24 \mathrm{hr}$.

Following isolation of the trachoma agent in the yolk sac of chick embryos (T'ang, Chang, Huang \& Wang, 1957) it was propagated successfully in epithelial cell cultures, producing a widespread cytopathic effect typical of the psittacosis group (Furness, Graham, Reeve \& Collier, 1960; Bernkopf, Mashiah \& Maythar, 1960). Electron microscopical study of such a system seemed an opportune means of gaining more precise information, in morphological terms, about multiplication of the trachoma agent, and so perhaps of the psittacosis group as a whole.

\section{METHODS}

Cell cultures. Stock cultures of HeLa cells in $250 \mathrm{ml}$. bottles were grown in a medium consisting of Gey's balanced salt solution, $10 \%(v / v)$ human serum inactivated at $56^{\circ}$ for $30 \mathrm{~min}$. and $0.5 \%$ (w/v) lactalbumin hydrolysate, with streptomycin $200 \mu \mathrm{g}$. $/ \mathrm{ml}$. Cells were subcultured into half test tubes containing $7 \mathrm{~mm} \times$ $22 \mathrm{~mm}$. coverslips, using the same medium but without antibiotics.

Inoculum. The T'ang TE55 strain of the trachoma agent (T'ang et al. 1957), originally supplied to us by $\mathrm{Dr}$ L. H. Collier (The Lister Institute) was maintained in this laboratory by serial yolk-sac propagation in chick embryos (Collier \& Sowa, 1958). Infected yolk-sac tissue was ground in a tissue grinder with $\mathbf{0 . 8 5} \%$ saline containing $1 \%(\mathrm{v} / \mathrm{v})$ horse serum and $10 \%(\mathrm{v} / \mathrm{v})$ nutrient broth, centrifuged at $2500 \mathrm{rev} . / \mathrm{min}$. for $10 \mathrm{~min}$., and the supernatant fluid stored in sealed glass capillaries at $-70^{\circ}$.

Assay and inoculation. The infectious material was titrated in HeLa cells by a method essentially similar to that of Furness, Graham \& Reeve (1960). An inoculum capable of infecting 90-100\% of the cells was prepared by 1/100 dilution of the yolk-sac material in Gey's solution; $0.5 \mathrm{ml}$. of inoculum in each tube was left to adsorb for $1 \mathrm{hr}$. at $37^{\circ}$. It was then removed, fresh antibiotic-free medium added, and incubation continued at $37^{\circ}$.

Electron microscopy. Infected cultures were processed for electron microscopy, together with uninoculated controls, at intervals of $6,12,24,48$, and $72 \mathrm{hr}$. after inoculation. The samples for each time consisted of pooled cells from batches of six tubes. The culture medium was first removed, and replaced with $3 \mathrm{ml}$. of the $1 \%(\mathrm{w} / \mathrm{v})$ osmium tetroxide fixative of Palade (1952) at $\mathrm{pH} 7 \cdot 4$; after a few minutes the cells were pushed gently from the tube walls into the fixative by using a rubber tipped glass rod. The contents of the six tubes were mixed and fixation continued for $1 \mathrm{hr}$. at room temperature. In loose pellet form the cells were then washed, dehydrated, and infiltrated with methacrylate monomer in the usual way. Final embedding was in a prepolymerized $1+4$ mixture of methyl and $n$-butyl methacrylates, catalysed with $1 \%(\mathrm{w} / \mathrm{v})$ benzoyl peroxide. Blocks of suitable hardness resulted from standing at $60^{\circ}$ for $24 \mathrm{hr}$.

Sections were cut with a Porter-Blum microtome and collected on copper grids bearing carbon-stabilized nitrocellulose films. Before examination most of the 
grids were floated face downwards for $3 \mathrm{hr}$. on a solution of $5 \%(\mathrm{w} / \mathrm{v})$ uranyl acetate in $1 \%(\mathrm{v} / \mathrm{v})$ acetic acid (Valentine, 1962), washed vigorously for about 30 sec. in distilled water and allowed to dry. The lead hydroxide method of Dalton \& Zeigel (1960) was also used. The sections were viewed with a Siemens UM 100 electron microscope operating at $60 \mathrm{kV}$; pictures were taken at $\times 1250$ or $\times 7000$ on ultrafine grain Ilford N.60 (photomechanical) plates, and subsequently enlarged.

Light microscopy. The progress of cytopathic change in the cultures was assessed, before electron microscopy, by inspection of the coverslips placed for this purpose into the culture tubes. Coverslips from each of the inoculated batches, and from uninfected control tubes, were fixed for about $20 \mathrm{~min}$. in Palade's buffered osmium tetroxide solution; after rinsing in Gey's solution they were transferred to $70 \%(\mathrm{v} / \mathrm{v})$ ethanol in water for about $24 \mathrm{hr}$. They were then mounted in water, wax-sealed and examined by phase-contrast microscopy as described elsewhere (Armstrong \& Pereira, 1960). Similar monolayers were stained by the periodic acid-Schiff (PAS) method for demonstration of polysaccharides, and counterstained with haematoxylin. Identification of glycogen was confirmed by treatment of some cultures with saliva for $45 \mathrm{~min}$. at $37^{\circ}$, before PAS staining. A few coverslip cultures were ethanol-fixed for Giemsa staining.

\section{RESULTS}

\section{Phase-contrast microscopy}

Inspection of the osmium-fixed cell monolayers revealed a progression of cellular changes after inoculation. Those examined after $6 \mathrm{hr}$. were not visibly different from the control HeLa cells. After $12 \mathrm{hr}$. a small optically dense nodular mass was detectable to one side of the nucleus in many cells, and by $24 \mathrm{hr}$. a well-defined juxtanuclear inclusion was present in almost every cell. It had a vesicular mottled appearance and continued to enlarge until $72 \mathrm{hr}$. after inoculation, when the experiment was terminated. The cells were then grossly distended, in each the nucleus was displaced to the periphery by a very large vesicular inclusion containing aggregates of dense particulate material (Pl. 1, fig. 1). These findings are in line with recent descriptions of trachoma-infected tissue cultures (Gordon, Quan \& Trimmer, 1960; Furness, Graham, Reeve \& Collier, 1960; Bernkopf et al. 1960), and comparable with the earlier accounts of changes that accompany multiplication of other members of the psittacosis group (Bedson \& Bland, 1932). The cytopathic changes developed synchronously throughout the cell sheets; counts indicated that more than $90 \%$ of the cells were infected at the outset. At $72 \mathrm{hr}$. the presence of a few cells with 'early-type' inclusions suggested the onset of a second cycle of growth.

\section{Electron microscopy}

The elementary body. Observations were directed first towards the contents of the fully developed inclusion or vacuole, in cells fixed $\mathbf{7 2} \mathrm{hr}$. after inoculation. The object was to determine the structural features of the infectious trachoma elementary bodies, believed to occur in the inclusion at this late stage, before attempting to interpret changes leading to their formation. There was no difficulty in finding inclusions in the sectioned cells. They contained a large number of small, rounded or oval particles of high electron density dispersed within a matrix of very much 
lower density. Measurements gave an average particle size of $375 \times 265 \mathrm{~m} \mu$, mean diameter about $320 \mathrm{~m} \mu$. The long axes of those presenting an oval profile were invariably orientated in one direction, suggesting that truly spherical structures had undergone the usual compression on sectioning. When allowance is made for differences due to the plane of section, the regularity in size and form of the dense particles was such as would be expected of viral elementary bodies.

Part of a typical $72 \mathrm{hr}$. inclusion is illustrated at high magnification in Pl. 1, fig. 2; the area shown contains four of the objects which we regard as elementary bodies. Each had a prominent and dense inner core (mean diameter $220 \mathrm{~m} \mu$ ) separated by a clear zone from a characteristically folded limiting membrane. The thickness of the membrane was about $10 \mathrm{~m} \mu$, but often looked more in the plane of a section because of its folded nature. This interpretation of cross-sections is entirely consistent with the 'wrinkled pea' description of intact elementary bodies, as revealed by electron microscopy of air-dried and metal-shadowed material from trachoma-infected chick embryos (Collier, 1959). The inner cores seemed on section to be of two kinds. One was a composite mass of fibrillar and granular elements, forming a compact structure with a regular outline. The other kind was less regular in outline and had the fibrillar component segregated from the granular part by a distinct but usually incomplete membrane. We shall refer to this saccular structure, which measured some $130 \mathrm{~m} \mu$ in diameter and was of great electron density, as a nucleoid (Pl. 1, figs. 2, 3). Inspection of random thin sections cannot establish whether an organized nucleoid is, in fact, entirely lacking in cores of the first kind; but it is conceivable that the variations in core structure signify different levels of particle maturity.

Appearance $6 \mathrm{hr}$. after inoculation. Many of the cells examined at this stage were not obviously different from those of the uninoculated control cultures. However, two abnormal features appeared quite often in the sections and were undoubtedly a consequence of the preceding inoculation. Pale mottled areas occurred in the cytoplasm ranging in size from small patches as seen in $\mathrm{Pl} .2$, fig. 4, to confluent masses larger than the cell nucleus. At high magnification they appeared to be largely amorphous but with a variable content of moderately dense $15-30 \mathrm{~m} \mu$ particles, closely comparable with the large type of glycogen deposits observed in liver cells after osmium fixation (Revel, Napolitano \& Fawcett, 1960). As a test of this interpretation, sections were floated on a solution of potassium permanganate as advocated by Drochmans (1960); the previously pale areas developed great electron density and became the most conspicuous objects in the cell cytoplasm. Further confirmation came from examination with the light microscope of PASstained monolayer cultures; almost all cells were seen to contain one or more large masses of PAS-positive material which was absent after saliva digestion. Negligible amounts of glycogen were demonstrable in the control cultures.

The other abnormality was a heterogeneous collection of small dense bodies in a juxtanuclear position, usually intermingled with the Golgi complex. Occasional structures of the same kind occurred in cells of the uninoculated cultures. A typical cluster within a cell inoculated $6 \mathrm{hr}$. previously is shown in Pl. 2, fig. 4. The profiles average some $350 \mathrm{~m} \mu$ in size, variation being attributable at least in part to plane of section. Until quite recently structures of this kind have been referred to in electron microscopical investigations in general terms, e.g. 'dense body', 'micro- 
body', 'lamellar body' and so on. Studies on mammalian liver cell structure (Essner \& Novikoff, 1960; Daems \& van Rijssel, 1961) have established the identity of peribiliary dense bodies as lysosomes, i.e. membrane-limited organelles containing acid phosphatase and other enzymes, which are directly concerned in phagocytic and lytic activities of the cell (De Duve et al. 1955). The morphological heterogeneity of lysosomes has been emphasized, but typically they contain ferritinlike granules and have a single limiting membrane. Many of the dense bodies with which we are presently concerned conformed to the descriptions of liver cell lysosomes and their presence would be consistent with recent phagocytic activity. Amongst them, however, was an occasional example having a dense fibrillo-granular central area surrounded by a markedly folded membrane. There was a superficial similarity between such forms and trachoma elementary bodies. Nevertheless, close examination of many cells fixed $6 \mathrm{hr}$. after inoculation did not reveal structures, in the cytoplasm or at the cell surfaces, that could be identified unequivocally as elementary bodies or their derivatives.

Appearance $12 \mathrm{hr}$. after inoculation. Some degree of alteration was now detectable in almost every cell examined. Lysosome aggregates were less obvious than at $6 \mathrm{hr}$., but large glycogen deposits were much in evidence. Light microscopy of PAS and haematoxylin-stained monolayers at this stage revealed, in addition to cytoplasmic glycogen, groups of basophilic particles in the general vicinity of the Golgi complex. They had the typical appearance of early developmental forms of the psittacosis group (Bedson \& Bland, 1932).

The first indication of structural elements presaging specific cytoplasmic inclusions was given in micrographs at this stage. At lower magnifications it was possible to detect in the cytoplasm more or less rounded formations, distinct from the glycogen and unlike any normal component of the HeLa cell. Ranging in size from under $1 \mu$ to more than $2 \mu$ in diameter, they had on section the consistency of a fine reticulum of low to moderate electron density. Several such reticular foci are depicted within a limited area of the cell cytoplasm in Pl. 3, fig. 5. Although sometimes grouped in this way, individual foci were also more widely scattered in the cells. At higher magnification each reticular focus appeared to consist essentially of a meshwork of delicate and wavy fibrils, usually bounded by a well-defined bilaminar membrane. In some, however, notably those over $1.5 \mu$ in diameter, the enclosing membrane was fragmentary or incomplete, the fibrillar contents being then in direct continuity with surrounding cytoplasm. Similar fibrillar material was sometimes observed without a vestige of a limiting membrane. No structures resembling elementary bodies were found.

Appearance $24 \mathrm{hr}$. after inoculation. There was no difficulty after $24 \mathrm{hr}$. in locating with the electron microscope characteristic juxtanuclear inclusions, corresponding to those observed by phase-contrast in the osmium-fixed monolayers. Indeed, they were of such size that at least part of one was encountered in almost every cell sectioned. The inclusion appeared as a localized area of altered cytoplasm several microns in diameter, with no equivalent in the uninoculated control cells. The presence of the abnormal structure caused slight indentation of the otherwise normal cell nucleus, and a corresponding bulge was often visible in the cell wall overlying the inclusion. Mitochondria, ribosomes and endoplasmic reticulum were absent from the area occupied by the inclusion, and abnormal glycogen deposits 
were distinctly smaller and less numerous than in the specimens fixed at $6 \mathrm{hr}$. and $12 \mathrm{hr}$. after inoculation.

The fine structure of the inclusion was remarkably constant from cell to cell. It consisted for the most part of a fibrillar matrix or reticulum of moderate overall density, incorporating somewhat denser patches each partially enclosed by an incomplete and fragmentary bilaminar membrane. The character of the inclusions suggested that the separate reticular foci seen at $12 \mathrm{hr}$. had become more numerous and were forming a confluent mass (Pl. 4, fig. 6). It was a regular finding that no membrane or other definable barrier separated the interior of the inclusion from the surrounding cell cytoplasm. Detail from a typical inclusion is shown at higher magnification in Pl. 5, fig. 7: curved profiles of several incomplete bilaminar membranes are present, and the components of the reticulum are seen as wavy fibrils, of high density and about $4 \mathrm{~m} \mu$ in thickness. Their length could not be determined from the study of sections. No elementary bodies were seen in the cells at this time.

Appearance 48 and $72 \mathrm{hr}$. after inoculation. A remarkable change in the character of the intracellular inclusions took place in the interval between 24 and $48 \mathrm{hr}$. after inoculation, accompanied by a considerable distortion of host-cell morphology. As anticipated from the preliminary phase-contrast observations there was pronounced enlargement of the inclusion, which now appeared as a distinctly vesicular formation with a diameter of $20 \mu$ or more. The cell nucleus was displaced to the side, markedly compressed by the inclusion but otherwise structurally unaltered. Recognizable cytoplasmic elements were restricted to a perinuclear area and a tenuous peripheral rim around the massive inclusion. Degenerative changes in the mitochondria were conspicuous in some cells. Little remained of the glycogen deposits seen at early stages.

As in the earlier stages, examination at high magnification revealed no continuous morphological barrier between the interior of the inclusion and the surrounding cytoplasm. The boundary is therefore probably a phase interface rather than a morphological entity. Each inclusion contained a number of discrete, more or less round bodies suspended within a matrix of comparatively low density (Pl. 5, fig. 8). The bodies were remarkably variable in size and structural detail, but all were alike in possessing a complete and well-defined limiting membrane; they will be referred to as developmental forms of the trachoma agent. The largest measured 3 or $4 \mu$ in diameter and the smallest between 300 and $400 \mathrm{~m} \mu$; different sizes occurred together in the majority of inclusions, but occasional cells appeared to contain only the larger ones. The larger developmental forms contained a reticulum of fibrillar nature similar to that observed, in an unenclosed form, in cultures examined at the $24 \mathrm{hr}$. stage. In addition, many of the larger forms also contained a number of prominent condensations of fibrillar material, round or oval in shape and about $300 \mathrm{~m} \mu$ in diameter (P1. 5, fig. 8). Complication of the cross-sectional morphology of the large forms frequently arose from the occurrence of deep finger-like invaginations of the limiting membrane, producing profiles of a bizarre nature. Inspection of developmental forms of decreasing size revealed a progression towards profiles of a more regular character, with increasing density and more even distribution of contents. Within forms typical of the intermediate size range (say, $0 \cdot 5-1 \mu$ in diameter) one or two centrally placed fibrillar condensations were separated from 
the limiting membrane by a wide zone occupied by material of a different nature, predominantly granular and of comparatively low electron density (Pl. 6, fig. 9). Developmental forms of smaller size than this became virtually indistinguishable from elementary bodies.

The cultures fixed $72 \mathrm{hr}$. after inoculation contained many cells similar to those seen at $48 \mathrm{hr}$.; but in general the inclusions were even larger and host-cell components correspondingly more displaced. Inside the inclusions elementary bodies predominated, with a reduced number of developmental forms of the large and intermediate sizes (Pl. 7, fig. 12; Pl. 8, fig. 13). In addition, a few disrupted large forms and some others that appeared to be intact but devoid of contents were often visible amongst the elementary bodies.

A considerable part of each inclusion was accounted for by the matrix in which developmental forms and elementary bodies were suspended. Owing to low overall density there was little to indicate its composition, except for scattered particles of moderate density, 20-50 $\mathrm{m} \mu$ in size, sometimes aggregated to form larger stellate clusters (Pl. 8, fig. 14). This is reminiscent of descriptions of particulate glycogen (Revel et al. 1960). This identification was borne out by the PAS-stained monolayer cultures; the contents of inclusion bodies were strongly PAS-positive from the $48 \mathrm{hr}$. stage.

Evidence of fission. Arbitrary classification of the developmental forms on a basis of size or structural differences cannot be justified; a whole range of transitional forms was recognizable in the electron micrographs, from the largest down to the elementary bodies. From comparison of the contents of cytoplasmic inclusions in 48 and $72 \mathrm{hr}$. specimens, it could be inferred that the larger developmental forms were somehow being replaced by those of smaller size. A search was therefore made for profiles that might be a key to inter-relationship of the various forms, bearing in mind the many previous reports of binary fission in the psittacosis group. In the $48 \mathrm{hr}$. inclusions there were always a few developmental forms so shaped, or disposed in relation to each other, as to suggest they had indeed been dividing at the time of fixation. Furthermore, it seemed that at least two modes of division could be recognized, namely into unequal or equal parts. Unequal division was shown mainly by the largest forms, and could be described as budding. Examples of it are illustrated in Pl. 6, fig. 10: here, two forms just a little larger than elementary bodies are each situated in close apposition to a comparatively large form, from which it could be supposed they were separating when fixed. The frequency of such associations made it unlikely they were entirely fortuitous; especially as large forms were also to be found showing localized protrusions which, though still continuous with the membrane of the parent body, exhibited varying degrees of intervening constriction. On the other hand, many intimately paired profiles of smaller developmental forms seemed to suggest division into equal halves (Pl. 6, fig. 11; Pl. 8, fig. 13). In general, the smaller the forms concerned, the more closely did their division approximate to binary fission as the term is generally understood. There were frequent signs of such divisions in the inclusions at $72 \mathrm{hr}$., when the larger developmental forms had mostly disappeared; and the possibility of elementary bodies undergoing repeated binary fission cannot be ruled out. 


\section{DISCUSSION}

The first systematic observations on the growth of psittacosis virus in infected tissues and cell cultures were based on conventional staining techniques for light microscopy (Bedson \& Bland, 1932, 1934; Bland \& Canti, 1935). Similar work was undertaken on the closely related causal agents of lymphogranuloma venereum and meningopneumonitis (Findlay, Mackenzie \& MacCallum, 1938; Rake \& Jones, 1942; Higashi, Notake \& Fukada, 1959). These researches have led to a wide measure of agreement about the cytopathic changes that accompany multiplication of the psittacosis group of organisms, the process culminating in a mass of newly formed elementary bodies less than $0.5 \mu$ in size. It has been generally considered that invading particles retain their integrity in the host cell cytoplasm and become transformed, after a latent period of 5 to $20 \mathrm{hr}$. into a visible cluster of comparatively large structures known as initial bodies, between 1 and $2 \mu$ in size. These seem to undergo repeated binary fission which, with a decrease in size, gives origin to the new infectious particles. The term 'plaque' was applied to large cytoplasmic structures of homogeneous appearance. Although plaques were first interpreted as plasmodia of viral nature (Bedson \& Bland, 1932) this view was later rejected in favour of regarding them as just closely packed colonies of initial bodies (Bedson \& Bland, 1984; Bedson, 1959). Light microscopy of cell cultures inoculated with the trachoma agent revealed an almost identical sequence of cytopathic changes (Gordon et al. 1960; Furness et al. 1960; Bernkopf et al. 1960). In this connexion it is interesting to recall that a similar developmental cycle was postulated many years ago after examination of cell inclusions in tissue from trachoma cases (Halberstaedter \& von Prowazek, 1907; Lindner, 1910).

Although light microscopy clearly demonstrates affinities within the psittacosis group, limited resolving power has impeded the understanding of early stages in the growth cycle. The uncertain nature of markedly pleomorphic developmental forms, and doubts concerning the degree of association between the infectious agent and the host cell, have been obstacles in the way of comparing satisfactorily the reproductive mechanisms of the psittacosis group and other micro-organisms such as the bacteria (Weiss, 1955; Trager, 1960). Already in several laboratories workers have turned to electron microscopy in the hope that greater resolving power would be decisive in the vexed question of taxonomic relationships. Thinsection studies have been made of cells infected with the agents of meningopneumonitis (Gaylord, 1954; Tajima, Nomura \& Kubota, 1957; Higashi, 1959), feline pneumonitis (Litwin, 1959), psittacosis (Litwin, Officer, Brown \& Moulder, 1961) and trachoma (Mitsui et al. 1958). Materials examined included tissues of infected animals and embryonated eggs, as well as inoculated cell cultures; but in terms of advancing previous knowledge the outcome has been inconclusive. Selective viewing of fragments from an organized tissue system is not an ideal basis for the analysis of a complex developmental cycle; and most of the published accounts deal chiefly with the structure of well-developed cytoplasmic inclusions. As pointed out by Higashi (1959) morphological changes giving origin to the large developmental forms have proved elusive; also, the internal structure of the elementary bodies has not so far been described in detail.

The findings of Tajima et al. (1957) in a study of chick chorioallantoic membranes, 
fixed at intervals from $2 \mathrm{hr}$. to 4 days after inoculation with the virus of meningopneumonitis, are of exceptional interest. For this group of workers reported a localized 'viral matrix' in the cytoplasm of infected cells, before the appearance of discrete developmental forms with limiting membranes. The matrix was described as granular, not sharply demarcated from the surrounding cell cytoplasm, and similar to the diffuse viroplasm characterizing the initial stages of intracellular multiplication of pox viruses. Nevertheless, Litwin et al. (1961) were unable to

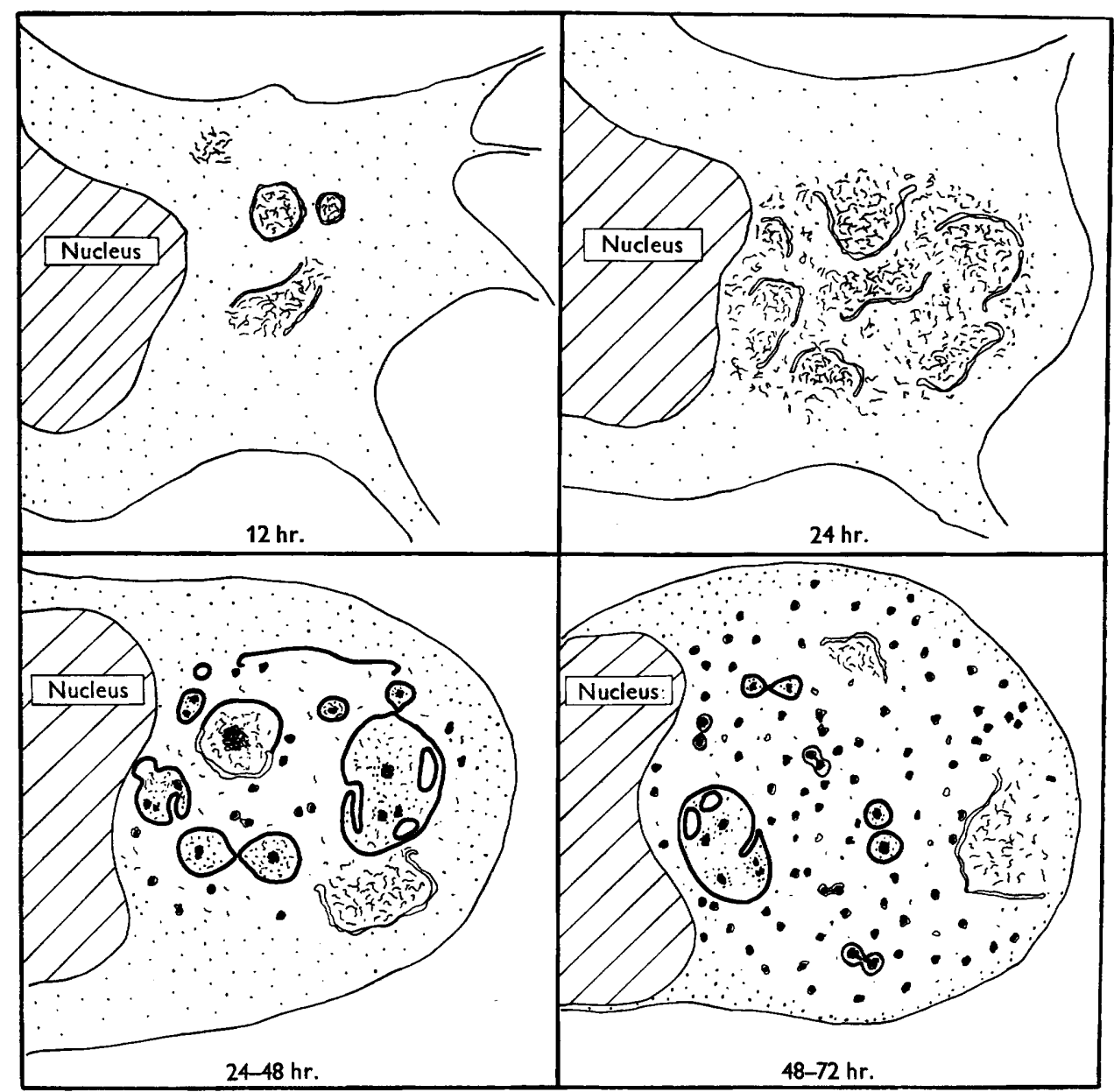

Fig. 1. Representation of stages in the developmental cycle of the trachoma agent in HeLa cells.

identify a similar matrix in psittacosis-infected chorioallantoic membranes; they concluded that a mechanism involving such elements 'cannot be an important means of multiplication in the psittacosis group'.

In the present investigation a regular sequence of changes was observed in HeLa cells inoculated with a high multiplicity of the trachoma agent. It has been possible from this to reconstruct some important aspects of the complex cycle of intra- 
cellular growth. Four significant stages are shown schematically in Fig. 1. The first was seen $12 \mathrm{hr}$. after inoculation, and is the stage of scattered reticular foci, with incomplete limiting membranes. Coalescence of these between 12 and $24 \mathrm{hr}$. produces the single inclusion of the stage of confluent reticulum. There can be little doubt that the formation which characterizes this stage corresponds to the disputed 'viral matrix' described by Tajima et al. (1957). In the period from 24 to $48 \mathrm{hr}$. the formation of new membranes within the inclusion gives rise to a series of spherical closed compartments, with a maximum diameter of about $3 \mu$. This is the stage of discrete developmental forms. Focal condensations occur within the larger forms, and between 48 and $72 \mathrm{hr}$. after the onset of infection, subdivision by means of budding and fission, with progressive diminution in size, gives rise to the final stage of newly formed elementary bodies. The mechanism by which newly formed elementary bodies escape from the inclusion remains obscure; transfer of individual elementary bodies through the cell wall to the exterior did not seem to be occurring in the material examined.

How infecting particles normally gain access to the host-cell cytoplasm, and their immediate fate thereafter, have not been elucidated. It is now certain that information on this could be expected only from close study of infected cells at a stage earlier than any in the present series. The demonstration recently of the phagocytosis and subsequent breakdown of vaccinia virus particles (Dales \& Siminovitch, 1961) encourages the speculation that infectious particles of trachoma, and others in the psittacosis group, may be taken into the cell in this way. Certainly, the finding of conspicuous lysosome aggregates $6 \mathrm{hr}$. after inoculation in the present series suggests that a high level of phagocytic activity had been taking place. We do not know whether each of the reticular foci seen in $12 \mathrm{hr}$. specimens had developed from a single infecting particle, or had been formed de novo after complete disintegration of the infecting particles.

In spite of these uncertainties, points of special interest revealed by the electron microscope are the incomplete separation of the contents of early reticular foci from surrounding cytoplasm, and their subsequent fusion into a confluent mass which is the definitive inclusion of the $24 \mathrm{hr}$. stage. The possibility has to be considered that the incomplete nature of the bilaminar membranes observed in early stages of the cycle was a technical artefact, due to disruptive polymerization of the methacrylate monomer or to defective fixation. Polymerization damage has characteristic effects on cellular fine structure (Morgan, Rose \& Moore, 1957) but evidence of this was encountered only in occasional blocks in this series. If polymerization damage is involved it would therefore be necessary to postulate unusual susceptibility of the early developmental forms of the trachoma agent. Fixation artefact can take various forms and is still little understood; it is therefore arguable that complete but delicate membranes may enclose the reticular foci, and be imperfectly preserved by the buffered osmium tetroxide method currently favoured by electron microscopists. In fact, it is difficult to envisage the observed fine structural details arising in this way, but we bring the view forward as one which cannot be entirely ruled out.

Correlation of electron microscopical details with the classical cytopathic changes associated with organisms of the psittacosis group seems to be largely a matter of terminology, presenting no great difficulty. Thus, the structures formerly termed 
'plaques' can reasonably be equated with the confluent reticulum seen at $24 \mathrm{hr}$. in the present study. Their plasmodial nature, hitherto conjectural, is borne out by electron microscopy. The precise equivalent of 'initial bodies' is less obvious; but it is likely that both the reticular foci and the later discrete developmental forms of the present account have been included together under this single heading in earlier descriptions. With both forms of microscopy it is possible to observe the innumerable elementary bodies within mature inclusions, but their internal structure is not of course represented in the images obtained with light microscopes.

It is of special interest to consider the fine structure of trachoma-infected cells in relation to recent cytochemical studies on the growth in cell cultures of several members of the psittacosis group, including the trachoma agent itself. The acridine orange fluorescence technique, together with nuclease digestion tests, has been used to demonstrate a series of regular changes in the distribution of nucleic acids in the cytoplasmic inclusions; the results were correlated with infectivity studies (Starr, Pollard, Tanami \& Moore, 1960; Pollard, Starr, Tanami \& Moore, 1960; Becker et al. 1962). During the first $24 \mathrm{hr}$., corresponding to the stages referred to here as scattered reticular foci and confluent reticulum, one or more small bodies became visible in the cytoplasm and then enlarged into a single juxtanuclear mass; this gave a strong red fluorescence signifying the accumulation of newly synthesized ribonucleic acid (RNA). As the mass enlarged further its red fluorescence tended to diminish and increasingly numerous points of intense yellow-green fluorescence emerged, indicating the development of particles containing deoxyribonucleic acid (DNA) within the preformed pool of RNA-containing material. This coincided with a rise of demonstrable infectivity. It was at about this stage in the present experiments, that discrete developmental forms were first seen in the micrographs. The presence of DNA may well be related to the more or less organized fibrillar component revealed in the elementary bodies by electron microscopy . Indeed, the ultrastructural complexity of the elementary bodies is consistent with the findings of chemical analysis which suggest that micro-organisms of the psittacosis group contain not only DNA, but also RNA and muramic acid (Zahler \& Moulder, 1953; Ross \& Gogolak, 1957; Allison \& Burke, 1962). A glycogen-containing matrix inside the fully developed cytoplasmic inclusions of trachoma-infected cells has been known for some years (Rice, 1936; Thygeson, 1938) and is merely confirmed by the present observations. However, the formation of widespread glycogen deposits in the host cell cytoplasm, as early as $6 \mathrm{hr}$. after inoculation, does not seem to have been noted previously; the possibility of this being a response to renewal of the culture medium, rather than to infection per se, is suggested by recent observations on fine structural variations in normal HeLa cells (Bruni, Gey \& Svotelis, 1961).

It is widely believed that the mode of intracellular replication permits a real distinction to be drawn between viral infection and parasitism by larger microorganisms. With viruses, breakdown of invading particles results in an intimate association between the infectious agent and the host cell, initiating the synthesis of viral components from which new infectious particles are assembled; the latter do not divide. It is generally accepted on the other hand that intracellular bacteria and rickettsias remain intact, multiplying by binary fission. Difficulty in the past over classification of the psittacosis group has been attributable partly to uncertainty 
concerning the degree of association between visible developmental forms and the cell, owing to limitations of the light microscope. However, complexity of the replicating mechanism for the trachoma agent is emphasized rather than diminished by electron microscopy of infected HeLa cells. The first part of the cycle is somewhat suggestive of a viral mechanism, in which derivatives of the infecting particles coalesce into a single mass of reticulum not obviously separated from the cell cytoplasm; but bacterial affinities are shown by the developmental forms which then emerge and give rise to elementary bodies through a series of divisions. In this developmental cycle the taxonomic dilemma is epitomized and it is hard to see how current concepts of viruses and bacteria allow the trachoma agent to be placed in either category. If an evolutionary process has yielded a succession of organisms decreasing in complexity from bacteria to the simplest viruses then border-line cases are only to be expected (Bedson, 1959), and their classification becomes an arbitrary question of definition. However, a theory now gaining support is that viruses and bacteria have entirely separate origins (e.g. see Allison \& Burke, 1962), in which case one may reasonably expect some absolute distinction between them. Which of the several properties generally held to distinguish viruses from bacteria should be regarded as absolute, is something which can emerge only from detailed study of both groups. Only when the true criteria are recognized can the position of organisms such as the trachoma agent be settled.

Our particular thanks are due to Dr Janet S. F. Niven, who suggested this study, for her continuing interest and advice; and to $\operatorname{Dr}$ L. H. Collier of the Lister Institute who kindly supplied us with infectious material. We also acknowledge gratefully the assistance of Miss Barbara Mantle in the tissue culture preparations, and of Mr M. R. Young, Mr R. D. Wood and Mr D. Kedgely in the preparation of illustrations.

\section{REFERENCES}

Alurson, A. C. \& Burke, D. C. (1962). The nucleic acid content of viruses. J. gen. Microbiol. 27, 181.

ANDREwes, C. H. (1952). Classification and nomenclature of viruses. Annu. Rev. Microbiol. 6, 119.

Armstrong, J. A. \& Pereira, H. G. (1960). Significance of cytopathic effects observed during the growth of adenovirus. Exp. Cell Res. 21, 144.

Becker, Y., Mashiah, P. \& Bernkopf, H. (1962). Biochemical changes in FL cell cultures infected with a trachoma agent. Nature, Lond. 193, 271.

BeDson, S. P. (1959). The psittacosis-lymphogranuloma group of infective agents. J. Roy. Inst. pub. Hlth, 22, 67, 99, 131.

Bedson, S. P. \& Bland, J. O. W. (1932). A morphological study of psittacosis virus with the description of a developmental cycle. Brit. J. exp. Path. 13, 461.

Bedson, S. P. \& Brand, J. O. W. (1934). The developmental forms of psittacosis virus. Brit. J. exp. Path. 15, 248.

Bernkopf, H., Mashiah, P. \& MaYthar, B. (1960). Cultivation of a strain of trachoma virus in the FL line of human amnion cells. Bull. Res. Counc. Israel, 8E, 121.

Bland, J. O. W. \& CaNTi, R. G. (1935). The growth and development of psittacosis virus in tissue cultures. J. Path. Bact. 40, 231.

Bruni, C., Gey, M. K. \& Svoted.Is, M. (1961). Changes in the fine structure of HeLa cells in relation to growth. Johns Hopk. Hosp. Bull. 109, 160.

Collien, L. H. (1959). Recent advances in the virology of trachoma, inclusion conjunctivitis and allied diseases. Brit. med. Bull. 15, 231. 
Collier, L. H. \& Sowa, J. (1958). Isolation of trachoma virus in embryonate eggs. Lancet, i, 993.

Daems, W. T. \& VAN RIJssel, T. G. (1961). The fine structure of the peribiliary dense bodies in mouse liver tissue. J. Ultrastr. Res. 5, 263.

Dales, S. \& Siminovitch, L. (1961). The development of vaccinia virus in Earle's L strain cells as examined by electron microscopy. J. biophys. biochem. Cytol. 10, 475 .

Dalton, A. J. \& Zeigel, R. F. (1960). A simplified method of staining thin sections of biological material with lead hydroxide for electron microscopy. J. biophys. biochem. Cytol. 7, 409.

De Duve, C., Pressman, B. C., Gianetto, R. J., Watticaux, R. J. \& Appelmans, F. (1955). Tissue fractionation studies. 6. Intracellular distribution patterns of enzymes in rat liver tissue. Biochem. J. 60, 604 .

Drochmans, P. (1960). Mise en évidence du glycogène dans la cellule hépatique par microscopie électronique. J. biophys. biochem. Cytol. 8, 553.

Essner, E. \& Novikoff, A. B. (1960). Human hepatocellular pigments and lysosomes. J. Ultrastr. Res. 3, $\mathbf{3 7 4}$.

Findlay, G. M., Mackenzie, R. D. \& MacCallum, F. O. (1938). A morphological study of the virus of lymphogranuloma inguinale (climatic bubo). Trans. R. Soc. trop. Med. Hyg. 32, 183.

Furness, G., Graham, D. M. \& Reeve, P. (1960). The titration of trachoma and inclusion blennorrhoea viruses in cell cultures. J. gen. Microbiol. $23,613$.

Furness, G., Graham, D., Reeve, P. \& Collier, L. H. (1960). The growth of trachoma and inclusion blennorrhoea viruses in cell culture. Rev. int. Trachome, 4, 574.

GaYLORD, W. H. (1954). Intracellular forms of meningopneumonitis virus. J. exp. Med. $100,575$.

Gordon, F. B., Quan, A. L. \& Trimmer, R. W. (1960). Morphologic observations on trachoma virus in cell cultures. Science, 131, 733.

Halberstaedter, L. \& Von Prowazek, S. (1907). Über Zelleinschlüsse parasitärer Natur beim Trachom. Arb. GesundhAmt., Berl. 26, 44.

Higashi, N. (1959). Electron microscopy of viruses in thin sections of cells grown in culture. Progr. med. Virol. 2, 43.

Higashi, N., Notake, K. \& Fukada, T. (1959). Growth characteristics of the meningopneumonitis virus in strain L cells. Ann. Rep. Inst. Virus Res., Kyoto Univ., B, 2, 23.

Lindner, K. (1910). Die freie Initialform der Prowazekschen Einschlüsse. v. Graefes Arch. Ophthal. 76, 559.

Litwin, J. (1959). The growth cycle of the psittacosis group of micro-organisms. J. infect. Dis. 105, 129.

Litwin, J., Officer, J. E., Brown, A. \& Moulder, J. W. (1961). A comparative study of the growth cycles of different members of the psittacosis group in different host cells. J. infect. Dis. 109, 251.

McCloskey, R. V. \& Morgan, H. R. (1961). Latent viral infection of cells in tissue culture. VIII. Morphological observations of psittacosis virus in L cells. Proc. Soc. exp. Biol., N.Y. 106, 85.

Mitsui, Y., Suzuki, A., Hanabusa, J., Minoda, R., Ogata, S., Fukushima, S. \& Miura, M. (1958). Structures of the initial bodies of trachoma inclusion as revealed in section by electron microscopy. Virology, 6, 137.

Morgan, C., Rose, H. M. \& Moore, D. H. (1957). An evaluation of host cell changes accompanying viral multiplication as observed in the electron microscope. Ann. N.Y. Acad. Sci. 68, 302.

Palade, G. E. (1952). A study of fixation for electron microscopy. J. exp. Med. 95, 285.

Pollard, M., Stark, T. J., Tanami, Y. \& Moore, R. W. (1960). Propagation of trachoma virus in cultures of human tissues. Proc. Soc. exp. Biol., N.Y. 104, 223.

RAKE, G. \& JoNES, H. P. (1942). Studies on lymphogranuloma venereum. I. Development of the agent in the yolk sac of the chicken embryo. J. exp. Med. 75, 323.

Revel, J. P., Napolitano, L. \& Fawcett, D. W. (1960). Identification of glycogen in electron micrographs of thin tissue sections. J. biophys. biochem. Cytol. 8, 575 . 
RrCE, C. E. (1936). The carbohydrate matrix of the epithelial-cell inclusion in trachoma. Amer. J. Ophthal., N.Y. 19, 1.

Ross, M. R. \& Gogolak, F. M. (1957). The antigenic structure of psittacosis and feline pneumonitis viruses. II. Chemical nature of the alkali-soluble antigens. Virology, 3, 365.

Starr, T. J., Polmard, M., Tanami, Y. \& Moore, R. W. (1960). Cytochemical studies with psittacosis virus by fluorescence microscopy. Texas Rep. Biol. Med. 18, 501.

Tajima, M., Nomura, Y. \& Kubota, Y. (1957). Structure and development of viruses of the psittacosis-lymphogranuloma group observed in the electron microscope. J. Bact. 74, 605 .

TAnami, Y., Pollard, M. \& STarr, T. J. (1961). Replication pattern of psittacosis virus in a tissue culture system. Virology, 15, 22.

T'ang, F. F., Chang, H. L., Huang, Y. T. \& Wang, K. C. (1957). Studies on the etiology of trachoma with special reference to isolation of the virus in chick embryo. Chin. med. J. 75, 429.

Thygeson, P. (1938). The matrix of the epithelial cell inclusion body of trachoma. Amer. J. Path. 14, 455.

Trager, W. (1960). In The Cell: Biochemistry, Physiology, Morphology, vol. 4, p. 151. Ed. J. Brachet and A. E. Mirsky. New York and London: Academic Press.

VAlentine, R. C. (1962). Contrast enhancement in the electron microscopy of viruses. Advanc. Virus Res. 8, 287.

WeIss, E. (1955). The nature of the psittacosis-lymphogranuloma group of micro-organisms. Annu. Rev. Microbiol. 9, 227.

ZAhLeR, S. A. \& Moulder, J. W. (1953). The incorporation of radioactive phosphate into feline pneumonitis virus in the chick embryo yolk sac. J. Infect. Dis. 93, 159.

\section{EXPLANATION OF PLATES}

All figures, with the exception of Pl. 1, fig. 1, are electron micrographs of thin sections of HeLa cells from cultures inoculated with the trachoma agent.

Plate 1

Fig. 1. HeLa cell coverslip culture $72 \mathrm{hr}$. after inoculation with the trachoma agent. In each cell there is a large vesicular inclusion and the nucleus has been pushed aside. Phase-contrast, after osmium tetroxide fixation $(\times 1850)$.

Fig. 2. High magnification of part of an inclusion in a $72 \mathrm{hr}$.-infected cell. Four sectioned elementary bodies are shown, in two of which the core is a compact fibrillo-granular structure. The other two have cores in which the fibrillar element is partially segregated within a saccular nucleoid. Note the folded limiting membranes $(\times 100,000)$.

Fig. 3. An elementary body with a particularly well differentiated oval nucleoid $(\times 100,000)$.

Plate 2

Fig. 4. Features of cytoplasmic fine structure $6 \mathrm{hr}$. after inoculation. A collection of pleomorphic lysosomes occupies a juxtanuclear position in the lower central part of the field. Low density glycogen-containing areas (Gl) were numerous and often larger than that illustrated. Normal elements include part of a cell nucleus $(N)$, the Golgi complex $(G c)$ and mitochondria $(M)(\times 25,000)$.

Plate 3

Fig. 5. Cytoplasmic reticular foci (RF), approximately $1 \mu$ in diameter, in a cell $12 \mathrm{hr}$. after inoculation. Note the incomplete limiting membranes around some of the foci. Unidentified smaller bodies (B) are possibly precursors of reticular foci $(\times \mathbf{2 3 , 0 0 0})$.

\section{Plate 4}

Fig. 6. A localized inclusion mass between the nucleus and cell membrane of a cell from a culture inoculated $24 \mathrm{hr}$. previously. The inclusion appears to consist of coalescent reticular foci $(\times 20,000)$. 

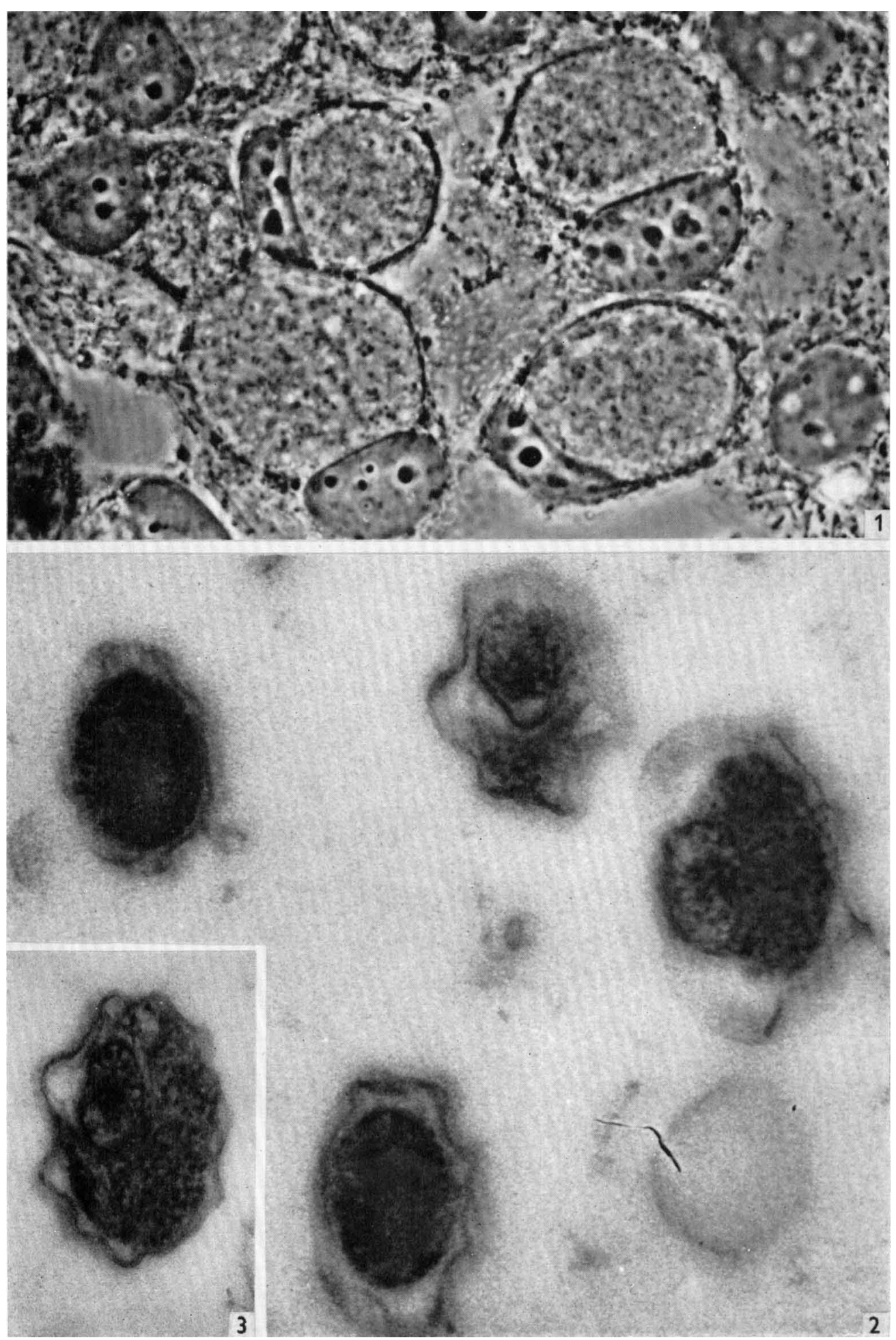


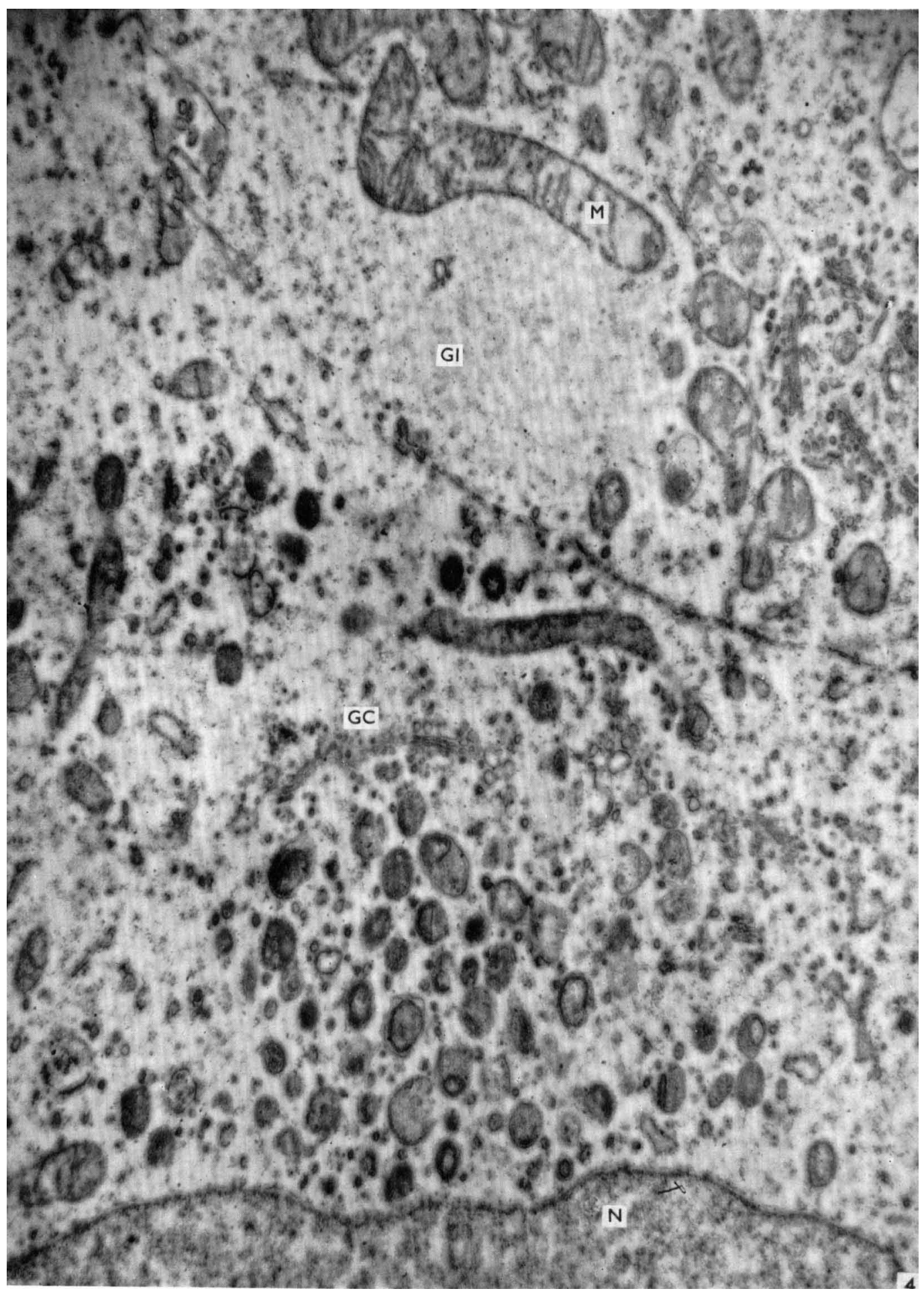

J. A. ARMSTRONG, R. C. VALENTINE AND C. FILDES 


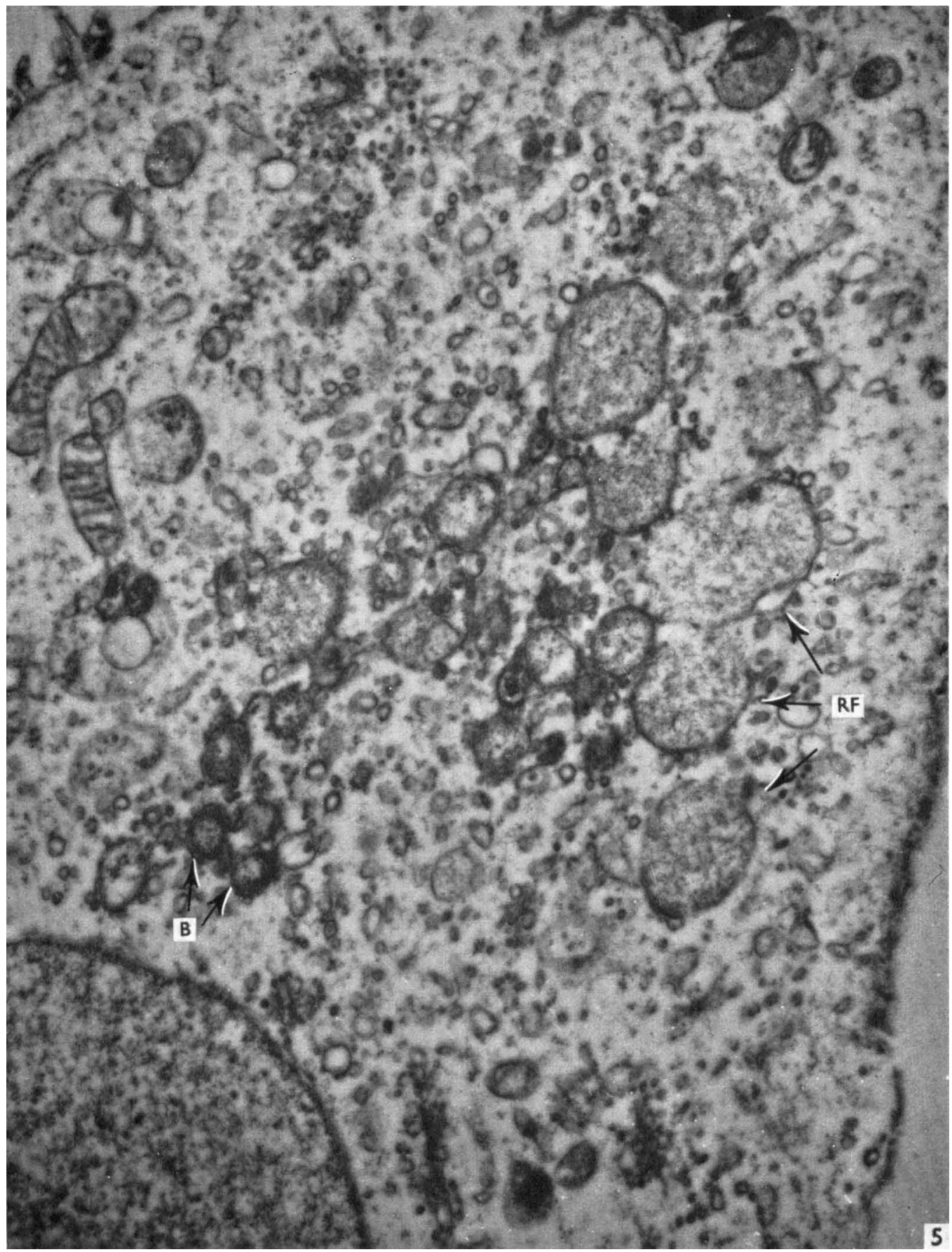

J. A. ARMSTRONG, R. C. VALENTINE AND C. FILDES 


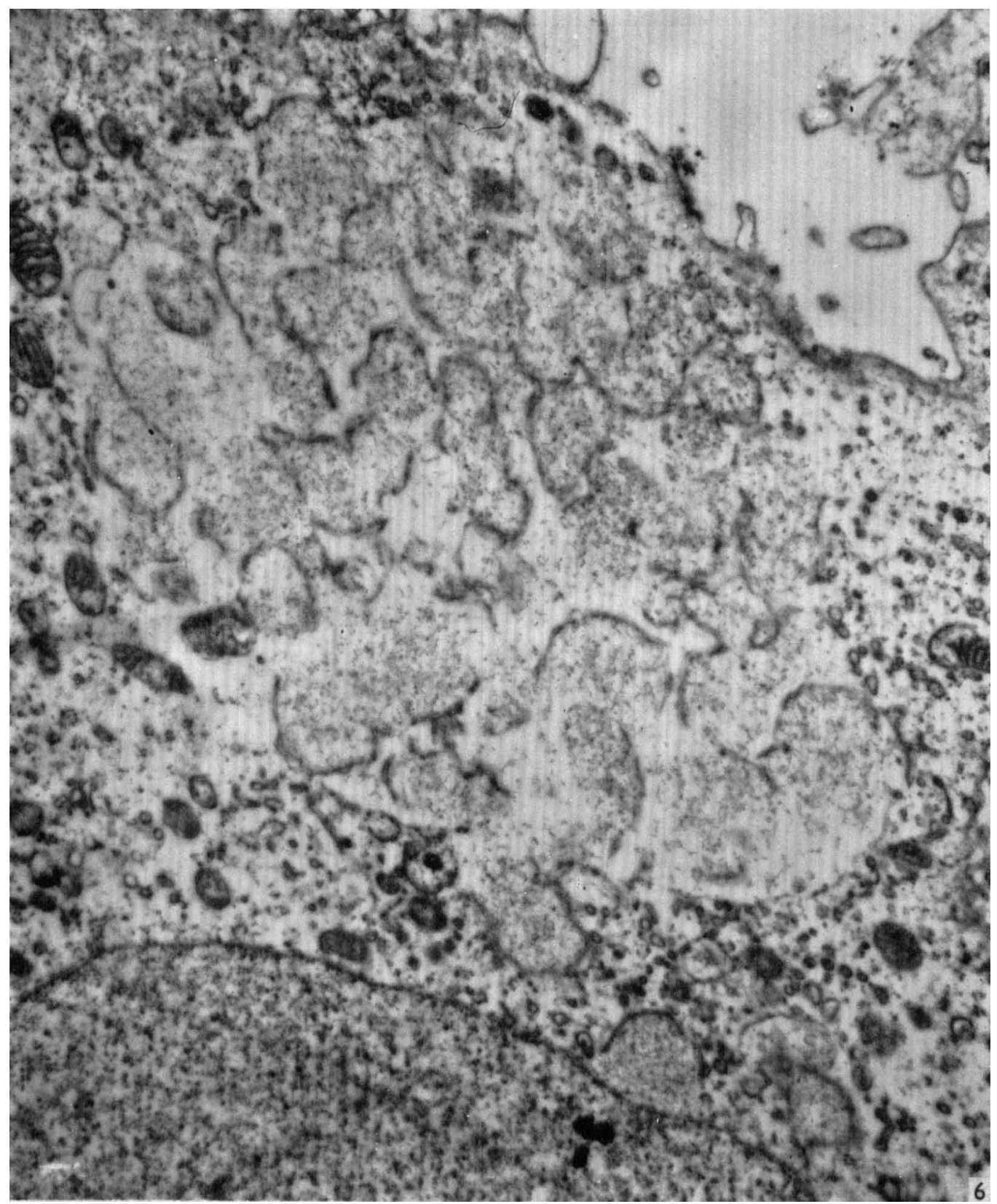

J. A. ARMSTRONG, R. C. VALENTINE AND C. FILDES 


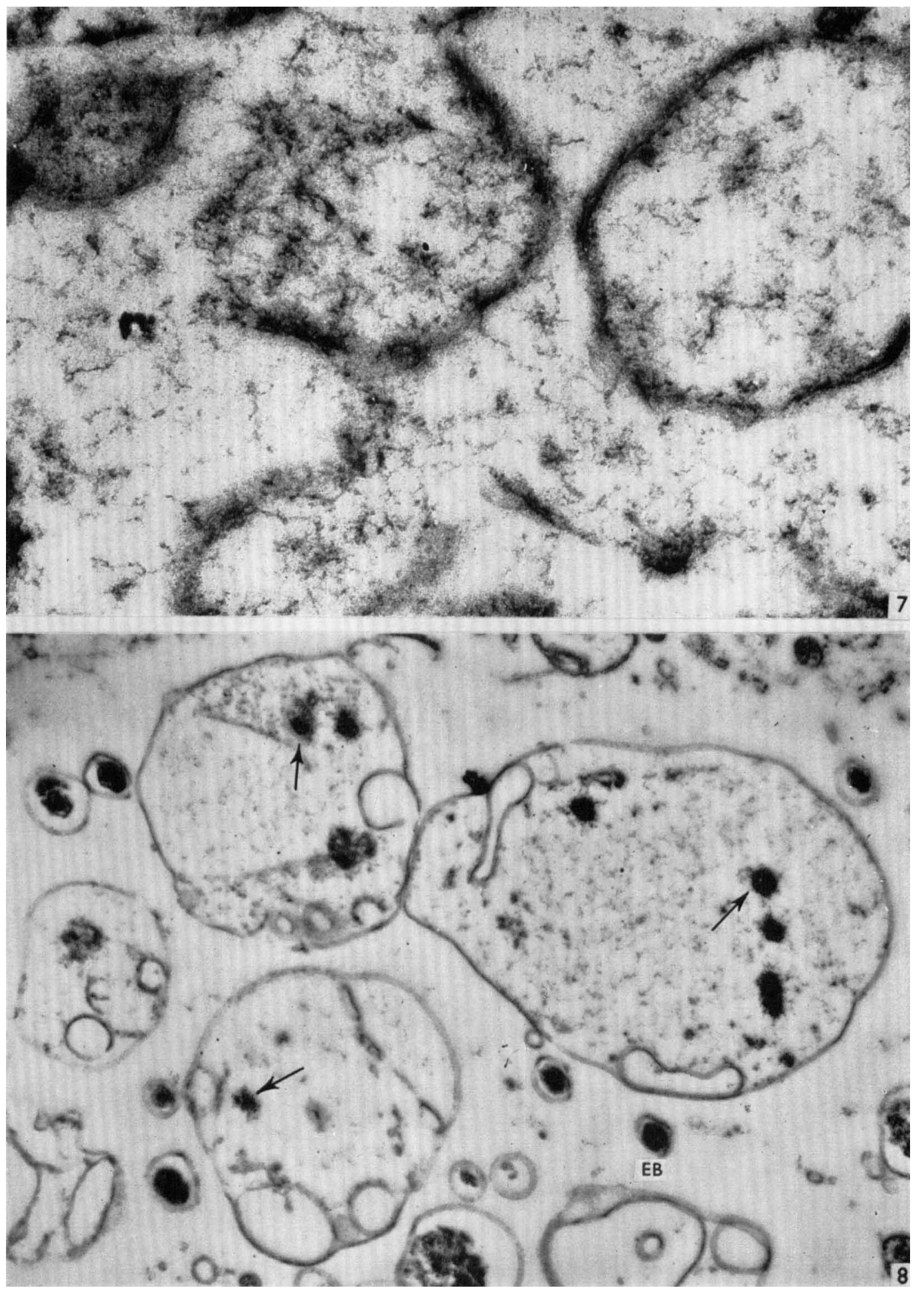

J. A. ARMSTrong, R. C. VAlen'tine and C. Fildes 
Journal of General Microbiology, Vol. 30, No. 1

Plate 6
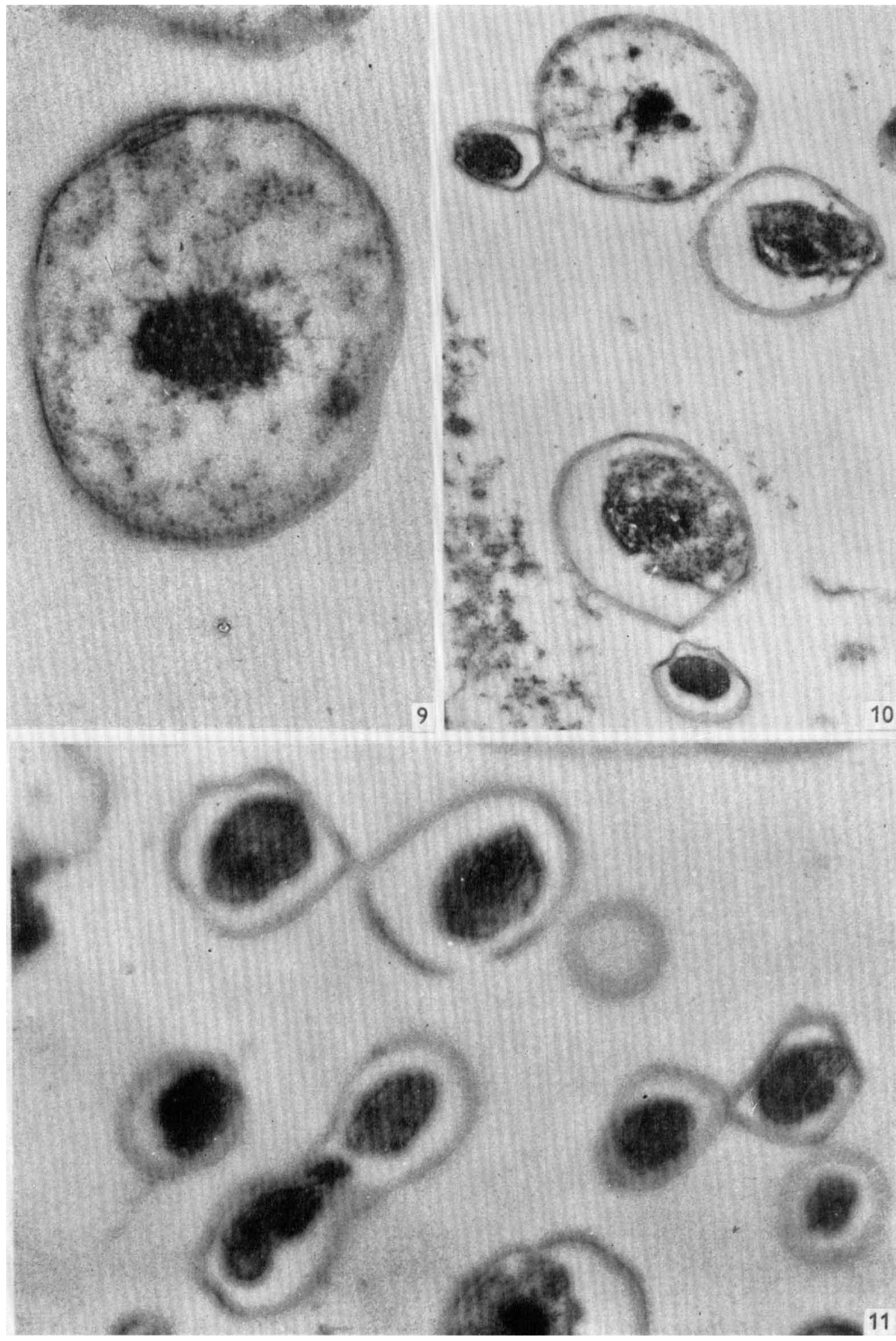

J. A. ARMSTRONG, R. C. VALENTINE AND C. FILDES 


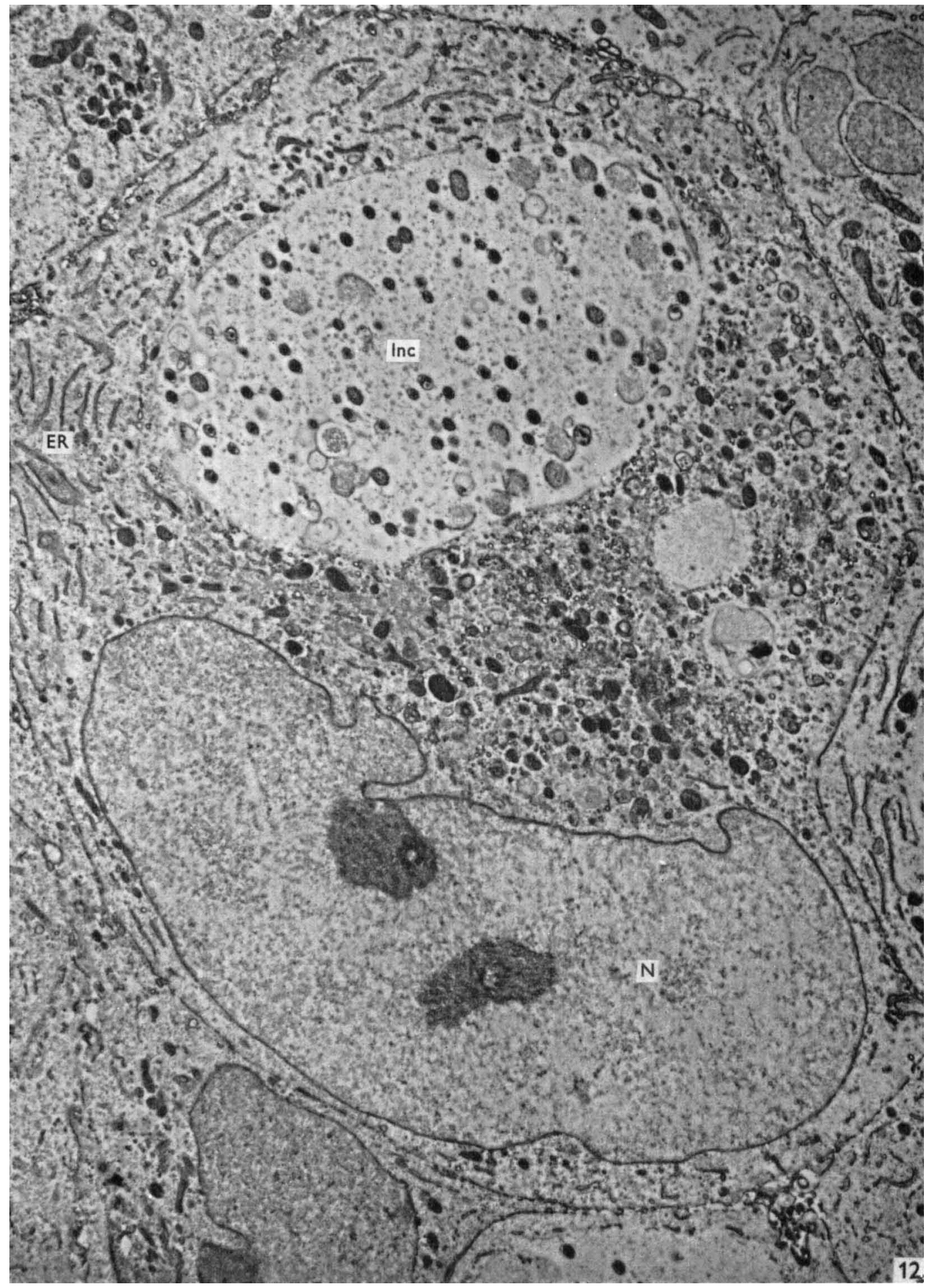



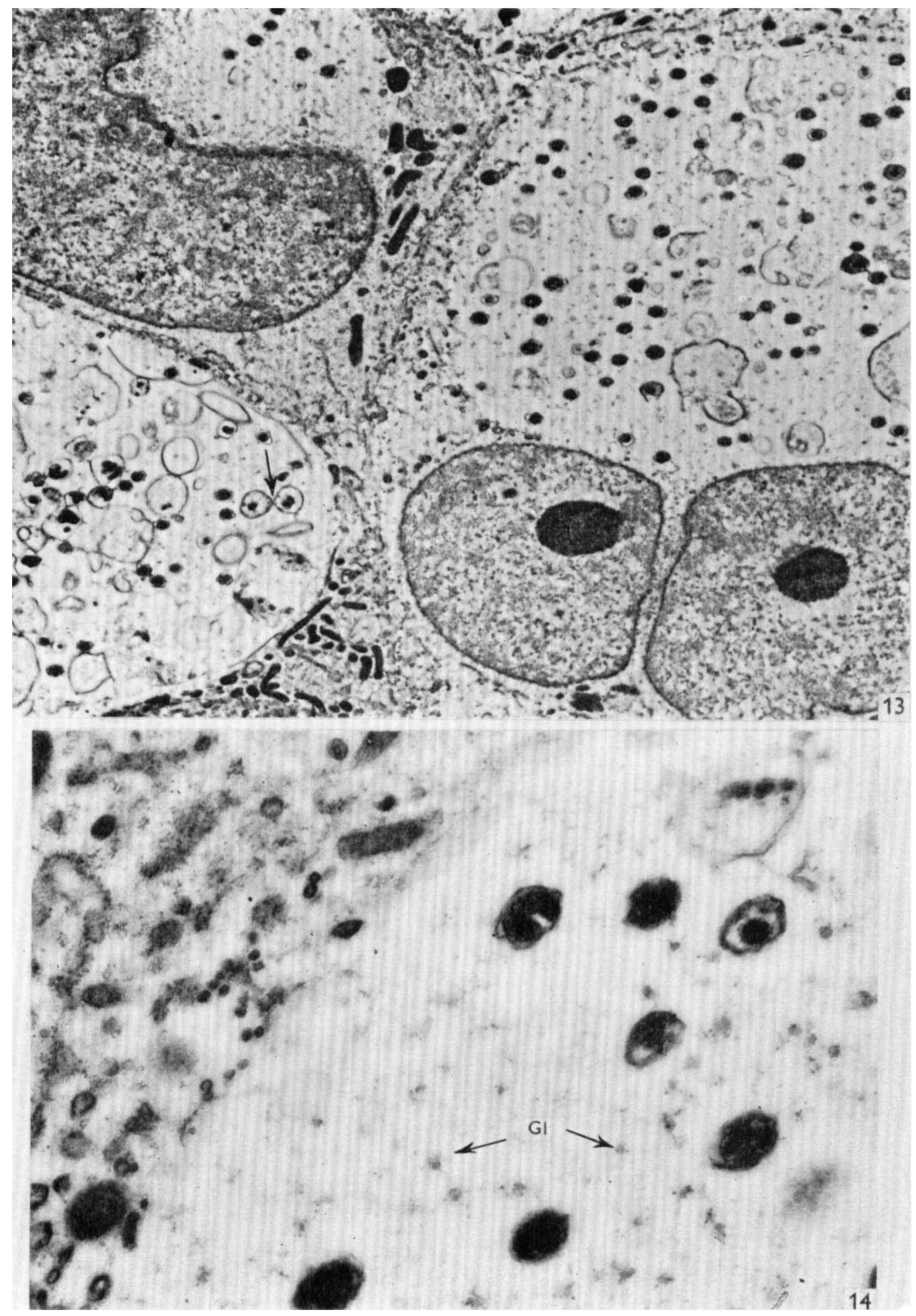

J. A. ARMSTRONG, R. C. VALENTINE ANd C. FILDES 


\section{Plate 5}

Fig. 7. A small part of a $24 \mathrm{hr}$. inclusion at higher magnification : the main visible component is a network of fine, electron dense fibrils. Remnants of the bilaminar membranes previously enclosing individual reticular foci are also present $(\times \mathbf{7 0 , 0 0 0})$.

Fig. 8. Large developmental forms with complete limiting membranes, contained in a typical inclusion $48 \mathrm{hr}$. after inoculation. Note the presence of several fibrillar condensations (arrows) inside the developmental forms; in between the latter are a few apparently complete elementary bodies (EB) $(\times 20,000)$.

\section{Plate 6}

Fig. 9. The structure of a discrete developmental form approximately $1 \mu$ in diameter, at high magnification. Note the central fibrillar condensation, separated from the limiting membrane by a wide zone containing scattered granular elements $(\times \mathbf{7 0 , 0 0 0})$.

Fig. 10. Profiles indicating the occurrence of unequal division, or budding, in a $48 \mathrm{hr}$. inclusion $(\times 35,000)$.

Fig. 11. Three paired profiles of relatively small developmental forms found in a section through a $72 \mathrm{hr}$. inclusion. They seem to indicate stages of division into equal halves $(\times 50,000)$.

\section{Plate 7}

Fig. 12. Section through a cell containing an inclusion, $72 \mathrm{hr}$. after inoculation. The relationship of the inclusion (Inc) to the host cell is clearly displayed. Its contents include numerous elementary bodies; it is embedded in cytoplasm containing elements such as mitochondria and endoplasmic reticulum (ER). The cell nucleus $(\mathbf{N})$ has been displaced but is structurally unaltered $(\times 5500)$.

\section{Plate 8}

Fig. 13. Typical cells in a $72 \mathrm{hr}$. infected culture. In each, the cytoplasmic area is largely taken up by an enormous inclusion. The inclusion to the right in the micrograph has many mature elementary bodies; whereas that at the lower left still contains developmental forms of various sizes some of which show signs of division (arrow) $(\times 6000)$.

Fig. 14. Section showing the edge of a fully developed inclusion. No distinctive membrane is visible between the inclusion and the surrounding cytoplasm. Note that between elementary bodies the matrix contains moderately dense granular material (Gl), probably particulate glycogen $(\times \mathbf{3 5}, 000)$. 